\title{
Substratum morphology and significance during the Weichselian Odra ice lobe advance in northeast Germany and northwest Poland
}

\author{
Piotr Hermanowski \\ Institute of Geology, Adam Mickiewicz University, Maków Polnych 16, 61-606 Poznań, Poland; \\ e-mail: piotr.hermanowski@amu.edu.pl
}

\begin{abstract}
In the Polish Lowlands, three main ice lobes, referred to as Odra, Vistula and Mazury, formed during the Last Scandinavian Glaciation. These lobes protruded at least several kilometres beyond the main ice margin and it is believed that they represent terminal parts of the ice streams. Applied geostatistical analysis based on numerous geological data has allowed an approximate reconstruction of the Odra ice lobe substratum in the area of northwest Poland and northeast Germany. A spatial representation of the Odra lobe substratum clearly illustrates the adverse slope of the glacier bed, but also indicates areas morphologically prone to ice streaming. It is suggested that the ice took advantage of local topography that enabled advance out of the Baltic basin; consequently, the ice followed a topographic low which, in combination with favourable hydraulic conditions of its substratum, likely initiated ice streaming.
\end{abstract}

Keywords: ice stream, last Scandinavian Ice Sheet, subglacial conditions, kriging

\section{Introduction}

In spite of the significant progress in glaciology and glacial geology made during the past decades many aspects still remain unclear or poorly understood. One of the major questions that is still a matter of debate concerns the processes that controlled the location of former as well as contemporary ice streams.

Based on modern research, the current dynamics of the West Antarctic ice streams depend of conditions at the ice/bed interface which facilitate bed deformation and basal sliding that vary in space (for details see e.g., Tulaczyk et al., 2000; Smith \& Murray, 2009). However, ice stream evolution and location seem to be no less complex. The West Antarctic Rutford ice stream occupies a deep trough (Smith \& Murray, 2009), but it is unclear whether it eroded a trough itself or took advantage of a pre-existing one. Generally, the occurrence of deep troughs has been linked to ice stream locations (Denton \& Hughes, 1981) which is justified since ice stream dynamics allow them to erode a trough if they persist in an area (Jennings, 2006). Evidence of ice stream activity on the West Antarctic continental shelf during the last glacial maxima was provided by Anderson et al. (2001). On the basis of multibeam echosounders, these authors demonstrated that megascale glacial lineations were confined to troughs. Another significant factor that influences motion and location of an ice stream are geological conditions. This factor plays an important role in the matter of effective pressure at the ice/bed interface with respect to different hydrogeological properties (e.g., Walder, 1982; Piotrowski, 1997a; Stokes et al., 2007; Hermanowski, 2010). 


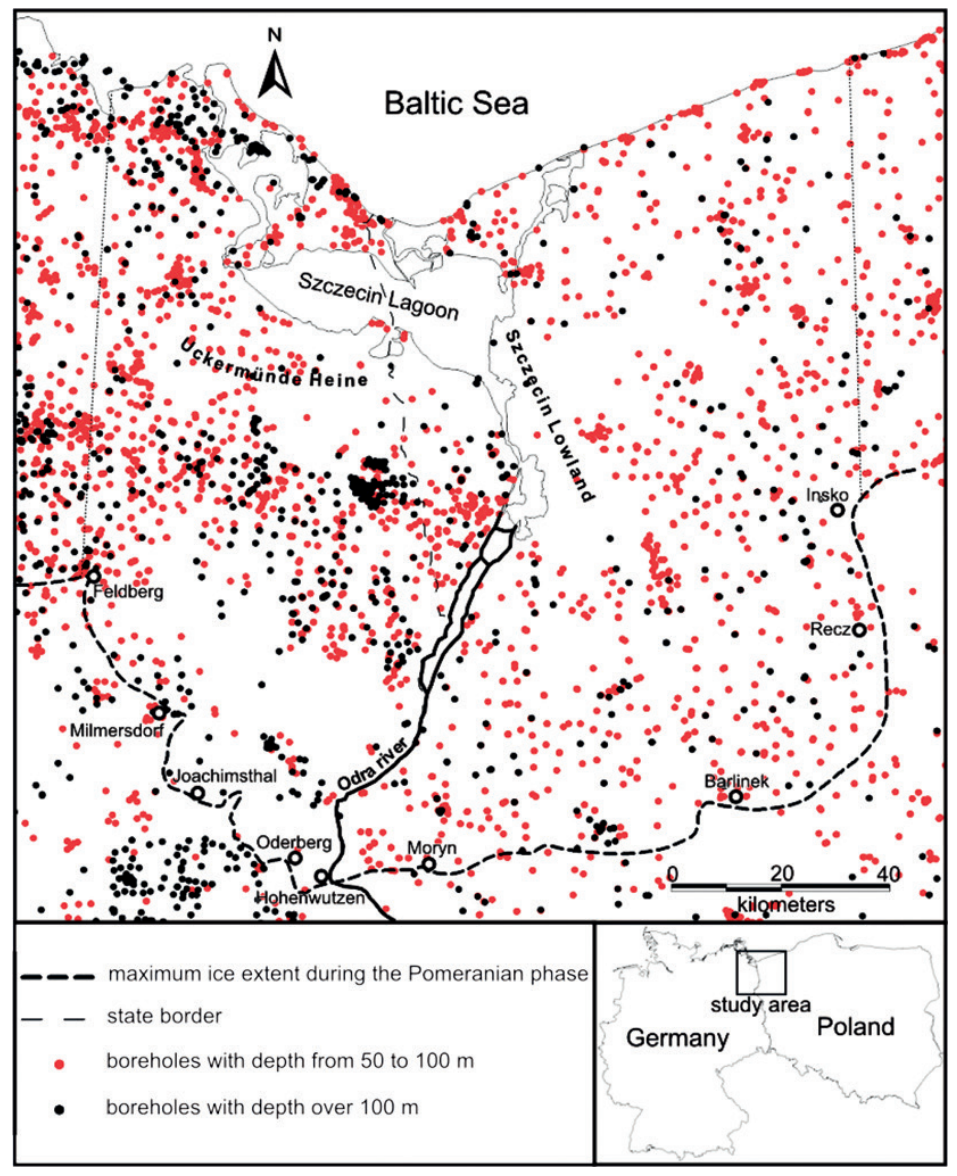

Fig. 1. Location of the study area and boreholes included
The concept of ice stream location during the Last Scandinavian Glaciation was first put forward by Punkari (1997) on the basis of basic geomorphological features such as end moraines. The concept proposed was further developed including evidence and timing of ice stream activity in the area (e.g., Jørgensen \& Piotrowski, 2003; Houmark-Nielsen, 2003; Houmark-Nielsen \& Kjær, 2003; Wysota, 2007; Przybylski, 2008; Kalm, 2012; Lasberg \& Kalm, 2013).

Directions and dynamics of ice sheet advance to the European lowland could be stimulated by different factors including the morphology of its substratum. In this paper I like to focus on an analysis and a reconstruction of the substratum of the Odra lobe, in particular in terms of the topographically preferential area for ice streaming. The central issue is whether or not the extent of the Odra lobe and pre-advanced land morphology were linked.

\section{Study area}

The study area is situated in the northwest of Poland and northeast Germany, and corresponds to the former location of the clearly visible
Weichselian Odra ice lobe (Fig. 1). The end moraine zone of this lobe represents the main ice margin during the Pomeranian phase (between $16.4 \pm 1.2$ to 17.3 \pm 1.2 ka BP; Rinterknecht et al., 2012; see also Heine et al., 2009) which has been recognised as a recession phase. However, it is believed that the Odra lobe formed early during ice advance to the European lowland and that its subsequent extent remained the same or was only slightly modified (Mojski, 2005; Hermanowski, 2007). The margin of the Odra lobe has been described mainly on the basis of geomorphological analysis (Keilhack, 1898; Woldstedt, 1931; Galon \& Roszkówna, 1961; Karczewski, 1968). The southern border of the Odra lobe stretches from Milmersdorf in the west through Joachimsthal, Oderberg to Hohenwutzen where it crosses the state border and continues further, on the Polish side, through Moryń, Barlinek and makes its way towards the north through Recz up to Insko where it curves to the east. The northern border of the study area is represented by the present-day Baltic Sea coast. The area specified covers about $18,500 \mathrm{~km}^{2}\left(\sim 7,900 \mathrm{~km}^{2}\right.$ in Germany and $\sim 10,600 \mathrm{~km}^{2}$ in Poland) and protrudes at least $40 \mathrm{~km}$ beyond the main Pomeranian phase ice marginal zone. 


\section{Methods}

Reconstruction of the Odra lobe substratum was carried out on the basis of Quaternary lithofacies map sheets (18 map sheets) at a scale of 1:50,000 for the German part of the lobe (Lithofazieskarten Quartär), and geological map sheets at a scale of 1:200,000 (6 map sheets) and 1:50,000 (12 map sheets) for the Polish part. These maps were supplemented by borehole logs obtained from the German Geological Survey of Brandenburg and Mecklenburg-Vorpommern (LBGR and LUNG M-V) and from the Polish Geological Institute. All borehole logs obtained were grouped into an extensive GIS data base which collects at least data on geographical co-ordinates, lithology and stratigraphy of 5,876 borehole logs each more than $50 \mathrm{~m}$ deep (Fig. 1). From this extensive data base supplemented by data taken from geological cross sections (cross sections are an integral part of mentioned geological map sheets) 2,037 points were selected on the basis of their location and depth, and these were subsequently digitalised. The aim of the data selection process was to obtain as many regularly spaced networks of data as possible. For each data point stratigraphic interpretation of geological units was done through comparison of borehole logs with the nearest geological cross section where stratigraphy is specified. All geological cross sections used here are an integral part of the geological map sheet. Even if, in some cases, the stratigraphy was described erroneously it is believed that in such an extensive data set it did not significantly influence the result of the interpolation. At first, all layers deposited during the ice overriding and thereafter were removed, i.e., all sediments postdating the Eemian. Thus, the reconstructed surface represents the top surface of the Saale till, which creates a near-continuous layer, as well as sand and gravel of the Eemian and early Weichselian. In the process of digitalisation, the altitude of the top surface of layers was described for each one point. Digitised data points were subsequently interpolated using a kriging procedure followed by variogram analysis resulting in a spatial representation of the Odra lobe substratum. The surface obtained was empirically evaluated and compared with geological cross sections in order to determine their accuracy.

\subsection{Interpolation procedure}

In order to estimate substratum morphology of the Odra lobe all data were interpolated using the kriging method which is the commonest and most realistic geostatistical approach in geological and morphological investigations (e.g. Goldsztejn \& Skrzypek, 2004). The kriging method is especially useful when digitised points are irregularly spaced (Davis, 1986; Goldsztejn \& Skrzypek, 2004). However, application of the method may be restricted in case of an insufficient number of data, and then it is suggested that instead of the conventional kriging procedure its modification - fuzzy kriging, which utilises exact measurement data and imprecise estimates is better used (Piotrowski et al., 1996). In the present study the collected data set consists of 2,037 data points which is considered sufficient. To estimate unknown values in the kriging method the weighted average of the samples is taken into consideration depending of the distance from the unknown area (Clark, 2001), so at a certain point the predicted value $f^{*}(x)$ is a linear combination:

$$
f^{*}(x)=\sum_{i=1}^{n} \lambda_{i} f\left(x_{i}\right)
$$

where $f\left(x_{i}\right)$ is the input point data set and the weights $\lambda_{i}$ are solutions of the systems of linear equations of the form:

$$
\lambda=\frac{1}{x \sum_{i=1}^{n} x_{i}}
$$

However, in many locations we have observed large differences in altitude also between nearby points. Some examples present in recently glaciated areas include end moraines, ridges and depressions left by the melt of ice-cored moraines, marginal kames, glaciotectonically disturbed sequences, eskers and others. In front of an ice margin terrain usually gradually slopes owing to existence of outwash plains. Such morphological characteristics are typical of the area along the Last Glacial Maximum (e.g. Houmark-Nielsen \& Piotrowski, 2000; Karczewski, 2001). Another important aspect in the interpolation procedure is the morphological anisotropy caused by natural geomorphological processes. In the areas mentioned assumption of linear variation would be unrealistic so the kriging procedure must be followed by variogram analysis. In consequence, issues of length scale, data repeatability and anisotropy, which are not functions of data locations are incorporated into the kriging algorithm through the variogram. The experimental semi-variogram can be formulated empirically as:

$$
\gamma^{*}(h)=\frac{1}{2 n} \sum(g(x)-g(x+h))^{2}
$$


where $g$ is the value at the co-ordinates $x$ and $x+h ; h$ indicates distance of two samples in the pair, and $n$ is the number of pairs. One of the most important aspects when developing variogram is to know what our data represent. We should also determine what kind of processes had a major influence on them. Considering the interpolation of geological layers morphology or geological material properties the knowledge of sedimentary or geomorphological processes would yield data on expected trends in the data, so to obtain reasonable and realistic result of the interpolation we should often apply anisotropy to the variogram model.

In this case the experimental variogram is arcuate so the simple linear variogram model seems to be inapplicable and eventually the exponential one was considered appropriate. Lag direction properties were set to 90 (Direction) and 75 (Tolerance) so the experimental variogram slightly differs from an omni-directional one. Assuming potential errors in the data the Nugget Effect was used with an error value of 50, this also causes smoothing of the resulting grid. The exponential variogram Length and Scale parameters were set by using an iterative approach to a value 38000 and 750, respectively. The Anisotropy settings are: Ratio 1.3 and Angle 90. The interpolation procedure using Surfer version 9.0 was done on a grid of rectangles where each cell is $c$. $500 \times 500 \mathrm{~m}$ wide what produces 322 rows and 371 columns. From the output grid, the Baltic Sea area was left blanked; therefore, the final grid contains 108787 filled nodes and 10675 blank ones.

\subsection{Validation of the interpolation procedure}

To find out if the interpolated surface differs from the input data and how significant the differ-

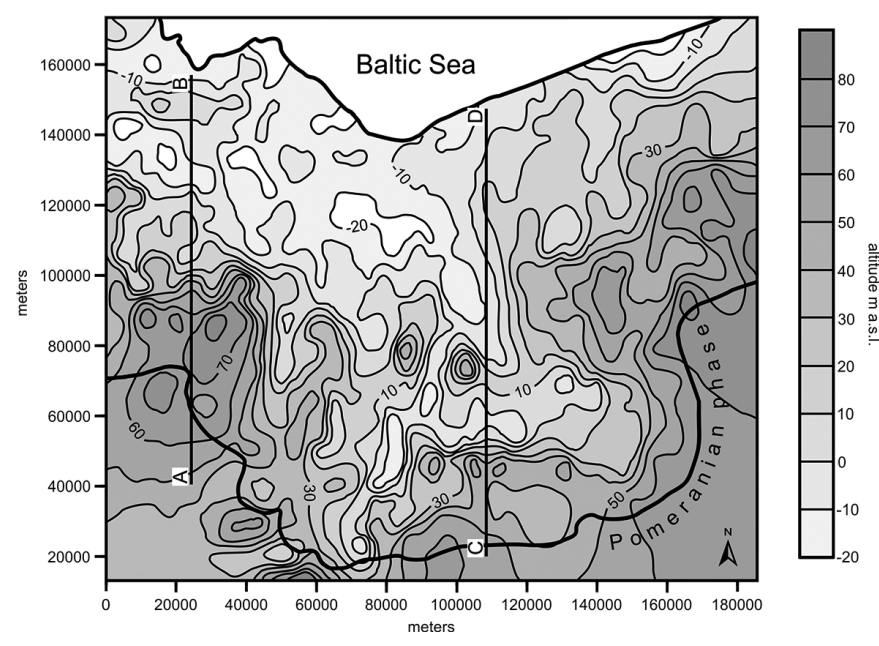

Table 1. Statistical parameters of residual values indicating a degree of discordance between input and interpolated data

\begin{tabular}{lrr} 
Statistical parameter & Residual values & $\begin{array}{c}\text { Absolute values } \\
\text { of residuals }\end{array}$ \\
\hline Number of values & \multicolumn{2}{c}{2037} \\
Sum & 8.9 & 6591.5 \\
Minimum & -27.4 & 0 \\
Maximum & 32.4 & 32.4 \\
Mean & 0.004 & 3.2 \\
Median & -0.003 & 2.2 \\
First quartile & -2.2 & 0.9 \\
Third quartile & 2.3 & 4.3 \\
Variance & 21.4 & 10.9 \\
Standard deviation & 4.6 & 3.3 \\
\hline
\end{tabular}

ence is in relation to the input data, the residual values $\left(Z_{r}\right)$ were calculated using the formula:

$$
Z_{r}=z_{d}-z_{i}
$$

where $z_{d}$ is the input value and $z_{i}$ is the interpolated value. As indicated by equation [4] the residual value represents the difference between the input value and the interpolated value at the same co-ordinates. Analysis of statistical parameters of residual values provides a quantitative measure of how well interpolated values agree with the input data. However, some statistical parameters can be very misleading owing to the fact that residual value can be positive or negative resulting, for example in very low (close to zero) sum of all values. Therefore, statistical parameters were also calculated for the absolute values of residuals which are a better indicator of the degree of discordancy between input and interpolated data (Table 1).

Calculated residual values show a rather large range of $59.8 \mathrm{~m}$, however, when we look at the value of first and third quartile $(-2.2 \mathrm{~m}$ and $2.3 \mathrm{~m}$,

Fig. 2. Morphology of the Odra ice lobe substratum. A-B and C-D indicate the location of the topographic sections (Fig. 5). The extent of the Pomeranian ice-sheet is marked 
respectively) we can conclude that the majority of interpolated data do not differ significantly from the original data. The representative values of mean and median can be derived from the absolute values of residuals which amount to $3.2 \mathrm{~m}$ and $2.2 \mathrm{~m}$, respectively. Taking into consideration the aim of the present study mean difference between input data and resultant data of about $3 \mathrm{~m}$ appears to be acceptable. All other statistical parameters are listed in Table 1.

\section{Spatial representation of the ice substratum}

The reconstructed ice substratum clearly illustrates the adverse slope of the glacial bed in relation to the direction of ice advance that is a downward slope towards the north (Figs. 2 and 3). An average elevation difference between the present-day Baltic Sea coast and the maximum ice extent of the Odra lobe is $c .50 \mathrm{~m}$. The minimum altitude is $c .-30 \mathrm{~m}$ a.s.l. while the maximum is c. $90 \mathrm{~m}$ a.s.1. Areas with a reconstructed elevation below $-10 \mathrm{~m}$ a.s.l. (Fig. 4) are found mainly in the areas of the Szczecin Lagoon and Uckermünde Heine localised in the north and northwest part of the study area (Fig. 1). The highest elevations, above $70 \mathrm{~m}$ a.s.l., cover a relatively small area primarily located outside of the central part of the Odra lobe (Fig. 4). The medium altitude for the whole area is c. $30 \mathrm{~m}$ a.s.l. and median is c. $25 \mathrm{~m}$ a.s.l. The medium altitude values (between 25 and $35 \mathrm{~m}$ a.s.1.) are mainly located in a thin zone at some distance inside the ice margin (Fig. 4). With a certain degree of simplification we can note that isolines of mean altitude values are parallel to the maximum ice extent. One notable exception

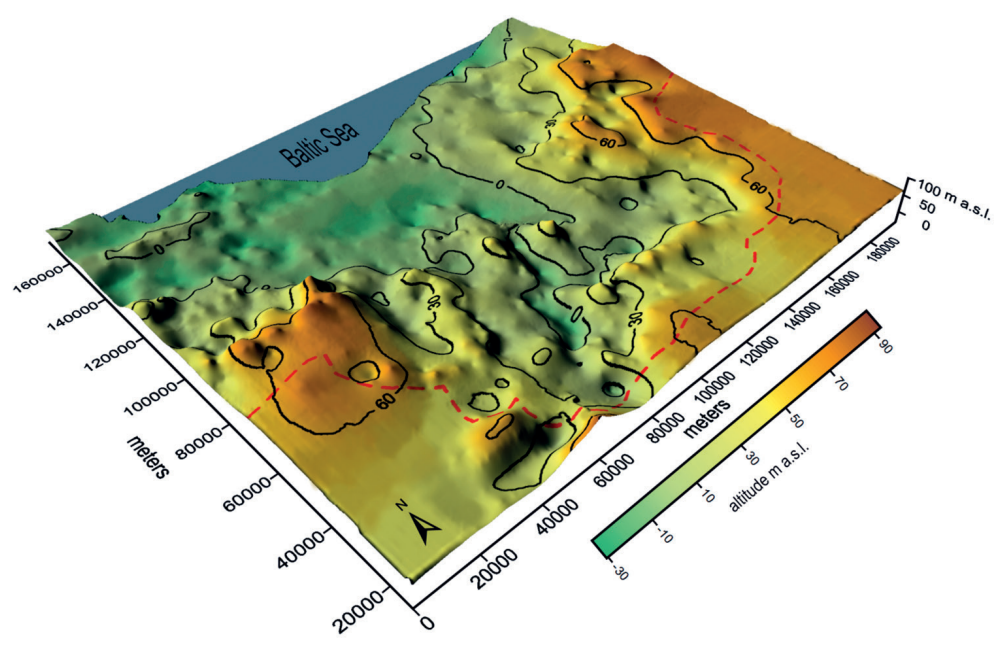

Fig. 3. Perspective image of the Odra ice lobe substratum with notably extensive low-lying north and central parts and a part of higher elevation in the vicinity of the maximum ice extent. Red dotted line represents maximum of ice extent during the Pomeranian phase

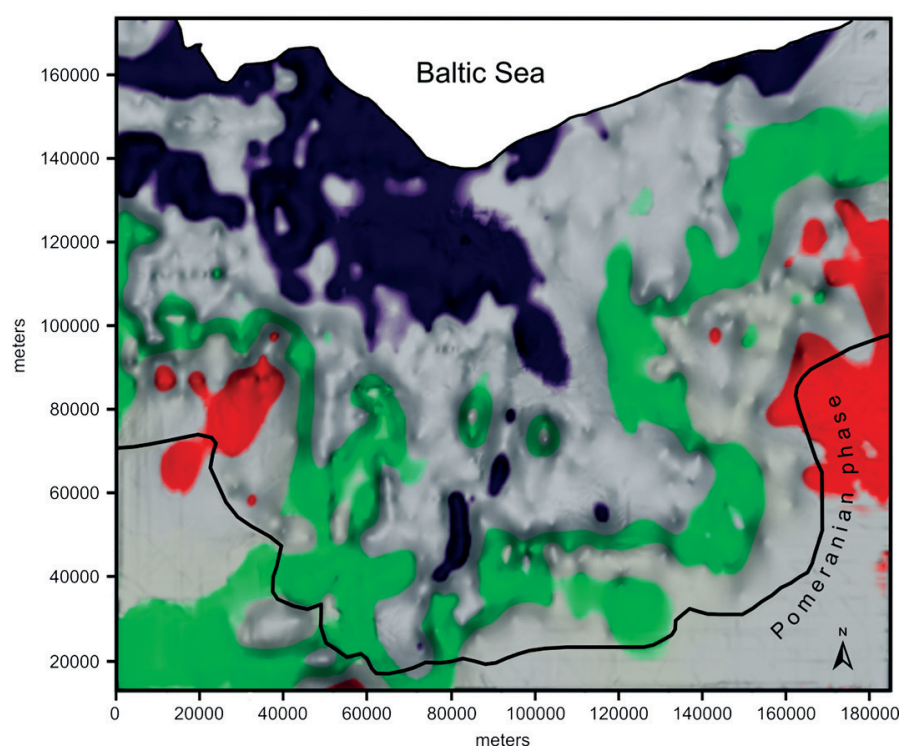

Fig. 4. Shaded image of the ice substratum with selected zones of elevation below $-10 \mathrm{~m}$ a.s.l. (blue), medium elevation zone between 25 and $35 \mathrm{~m}$ a.s.l. (green), and elevation area above 70 $\mathrm{m}$ a.s.l. (red). Note parallel location of the mean altitude zone and the maximum ice extent 

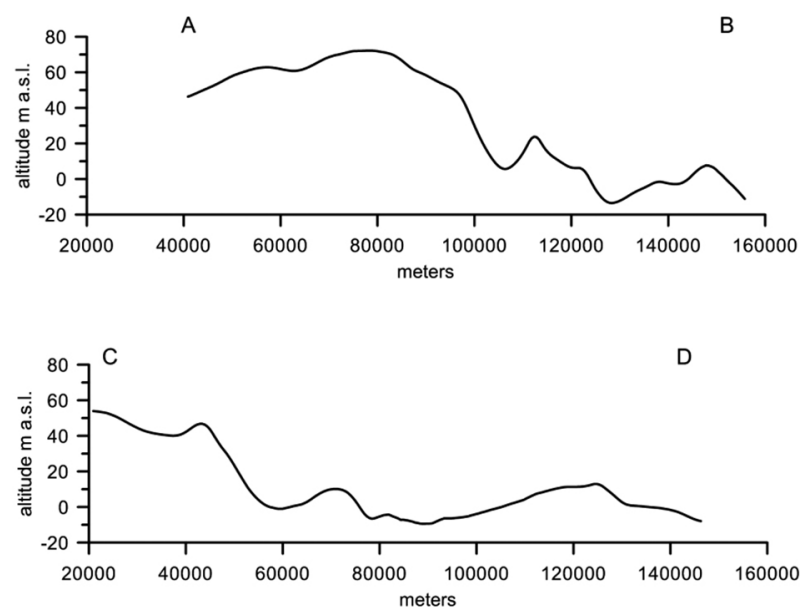

Fig. 5. Cross sections illustrating the notable adverse slope of the glacial bed (see Fig. 2 for locations)

from the above is observed in the south-central part of the lobe. The zone of the mean altitude values also indicates a significant slope of the substratum relative to the rest of the area and divide the area into an extensive low-lying north and central part, and a part of higher elevation in the vicinity of the maximum ice extent (Fig. 3), this is clearly visible in profile A-B and C-D (Fig. 5). Although both topographic profiles indicate relatively small variations of elevation it is easy to distinguish areas where the reconstructed ice substratum elevation significantly rises in relation to the rest of the area, and this part of the terrain coincide with the area of the medium altitude. Furthermore, the area of notable bed elevation rise delimits the main trough on the Odra lobe area. Within the central part of the reconstructed substratum hummocks built by the Saalian till can be distinguished which are parallel to the major direction of the ice flow. The elevation of hummocks exceeds that of their surroundings by about $40 \mathrm{~m}$ creating in the same way passages that run towards the terminus of the Odra lobe.

\section{Discussion and conclusions}

It is unquestionable that vast modifications of the Weichselian ice substratum in the study area took part during three major ice phases, i.e., the Poznań, Leszno and Pomeranian phases (e.g., Marks, 2002) so an accurate reconstruction of the ice substratum before its advance is impossible due to erosional, glaciotectonic and depositional events which partly blurred original landscape composition. However, thorough examination of pre-deposited sediments morphology in connection with geostatistical procedure can decipher palaeo-morphology in a generalised way providing support for further goals such as the reconstruction of ice sheet dynamics.

Placing the reconstructed area within a much broader glacial context, given that the Baltic Sea Ice Stream was the most extensive ice stream, as presented by Punkari (1997), and had a major influence upon the dynamics of the Scandinavian ice sheet discharging huge amounts of ice, we can consider its impact on the ice advance in the European lowlands. The location of the Baltic Ice Stream was schematically shown by Punkari (1997), illustrates the ice flow direction from the north through the Gulf of Bothnia to the south where it bends to the west filling the major part of the Baltic Sea and terminating at its westernmost extension as the land-based ice stream on Funen Island (Jørgensen \& Piotrowski, 2003). A high ice flow rate throughout the Baltic Basin was also suggested on the basis of numerical modelling (Holmlund \& Fastook, 1993). In such a case the ice likely took advantage of topographic lows in the European lowland typically occurring along river valleys. Therefore, the ice advance to the European lowland, at its early stage, could be initiated in topographically low areas, and consequently giving rise to the creation of ice streams directed further south. Referring to the map of the major ice streams of the Scandinavian Ice Sheet produced by Punkari (1997) the ice streams which advanced to the European lowland are named $\mathrm{B}^{2}, \mathrm{~B}^{3}$ and $\mathrm{B}^{4}$ terminating as large landbased outlets of the ice streams named the Odra, Vistula, and Mazury lobes respectively (e.g. Marks, 2005). The ice streams originated from the Baltic Sea Ice Stream and further developed southwards. The reconstructed broadly trough-shaped the Odra lobe substratum seems to have been favourable for the advancing ice margin in providing a potentially perfect output area for the fast-flowing ice which filled the Baltic basin. Similar topographic conditions occurred over Denmark where the ice stream advance was guided by topographic depressions (Houmark-Nielsen \& Kjær, 2003). It seems to be clear that in the study area the ice used local topography and eventually it became entrenched and followed a topographic low. Thus, even though there is no direct dating indicating in which areas the ice first advanced to the European lowland, we may speculate that the ice first advanced to topographically preferential areas like the Odra lobe area while general ice advance took place at a later time.

There is a general consensus that in the area of the European Lowlands during the last glaciation water was at least partly stored subglacially (in lakes) due to low hydraulic transmissivity of the ice substratum, high basic melting rate, and insuf- 
ficient drainage system (Piotrowski, 1997a, b; Hermanowski, 2010). Additionally, subglacial water storage is more likely when ice moves over a frozen bed (Boulton et al., 2009), so in conditions that likely occurred in the Odra lobe area (Piotrowski, 1994; Szewczyk et al., 2007). It is suggested that a subglacial drainage system was created in the late phase of ice advance (Hermanowski \& Piotrowski, 2009), and contributed to stabilisation of the ice sheet by evacuating large volumes of water from the ice/ bed interface (Piotrowski, 1994; Jennings, 2006; Hermanowski \& Piotrowski, 2007). Even though some subglacial water may have accumulated in pore space in dilated till (Hooke \& Jennings, 2006) its volume probably would not be sufficient enough to erode substantial tunnel valleys commonly found in the study area. Considering these conditions that occurred in the lobe area raise the question of location of subglacial water storage. Piotrowski (1994) suggested that the present Baltic Sea basin could have served as a subglacial water collector. However, the reconstructed topography of the ice substratum demonstrates ideal conditions for water storage about $10 \mathrm{~km}$ inside the ice margin where the highest adverse slope of the ice substratum is found. Although there is no geological evidence of subglacial water-filled depressions either close to the ice margin or in the Baltic Sea basin, it is possible that water was indeed stored in both locations.

The advancing Odra lobe margin could have divided into smaller lobes which were initiated owing to topographically preferential areas. Such areas prone to ice streaming are identified where the adverse slope is not so steep in the central part of the study area (Fig. 3), favouring faster ice flow over unconsolidated sediments of low permeability.

Reconstructed, favourable for ice streaming, substratum topography is comparable in size to the Odra lobe so should be postulated that its extent was partly topographically controlled. However, despite the fact that it was at least partially topographically controlled it does not rule out that temporal stabilisation of the ice sheet was due to evacuation of large volumes of basic meltwater that could have occurred during the initial stage of ice advance (Piotrowski et al., 2009; Hermanowski \& Piotrowski, 2009).

Questionable is also the origin of the reconstructed trough; however, it can be assumed that it formed during the Saalian and Elsterian glaciations involving both direct glacial erosion and meltwater erosion.

\section{Acknowledgements}

I thank two anonymous reviewers and the editor for constructive comments which helped to improve the manuscript. This study was supported by the National Science Centre (NCN) grant no. DEC2012/05/D/ST10/01168.

\section{References}

Anderson, J.B., Smith Wellner, S., Lowe, A.L., Mosola, A.B. \& Shipp, S.S., 2001. Footprint of the Expanded West Antarctic Ice Sheet: Ice Stream History and Behavior. Geological Society of America Today 11, 4-9.

Boulton, G.S., Hagdorn, M., Maillot, P.B. \& Zatsepin, S., 2009. Drainage beneath ice sheets: groundwater-channel coupling, and the origin of esker system from former ice sheets. Quaternary Science Reviews 28, 621-638.

Clark, I., 2001. Practical Geostatistics. Geostokes Limited, Alloa, 119 pp.

Davis, J.C., 1986. Statistics and Data Analysis in Geology. John Wiley \& Sons, New York, 646 pp.

Denton, G.H. \& Hughes, T.J., 1981. The Arctic Ice Sheet: An outrageous hypothesis. [In:] G.H. Denton \& T.J. Hughes (Eds): The Last Great Ice Sheets. Wiley, New York: 437-467.

Galon, R. \& Roszkówna, L., 1961. Extents of the Scandinavian glaciations and of their recession stages on the territory of Poland in the light of analysis of the marginal forms of inland ice. Przeglad Geograficzny 33, 347-364.

Goldsztejn, P. \& Skrzypek, G., 2004. Wykorzystanie metod interpolacji do numerycznego kreślenia map powierzchni geologicznych na podstawie nieregularnych danych [Applications of numeric interpolation methods to the geological surface mapping using irregularly spaced data]. Przeglad Geologiczny 52, 233-236.

Heine, K., Reuther, A.U., Thieke, H.U., Schulz, R., Schlaak, N. \& Kubik, P.W., 2009. Timing of Weichselian ice marginal positions in Brandenburg (northeastern Germany) using cosmogenic in situ ${ }^{10}$ Be. Zeitschrift für Geomorphologie 53, 433-454.

Hermanowski, P., 2007. Morfologia osadów podłoża zlodowacenia Wisły na obszarze polskiej części lobu Odry [Morphology of the Vistulain (Weichselian) glaciation substratum in the area of Polish part of the Odra lobe]. Przeglad Geologiczny 55, 133-139.

Hermanowski, P., 2010. Palaeoglaciology of the Weichselian Odra ice lobe, NE Germany and NW Poland. Landform Analysis 14, 12-24.

Hermanowski, P. \& Piotrowski, J.A., 2007. Substratum morphology, ice thickness estimation and the location of tunnel valleys as proxies in the reconstruction of the dynamics of the Odra lobe during the Last Glaciation. Schriftenreihe der Deutschen Gesellschaft für Geowissenschaften (Abstract-Volume) 53, 117.

Hermanowski, P. \& Piotrowski, J.A., 2009. Drenaż subglacjalny i jego wpływ na dynamikę lobu Odry zlodowacenia Wisły [Subglacial drainage and its influence 
on the dynamics of the Weichselian Odla lobe]. Przeglad Geologiczny 57, 504-512.

Holmlund, P. \& Fastook, J., 1993. Numerical modelling provides evidence of a Baltic Ice Stream during the Younger Dryas. Boreas 22, 77-86.

Hooke, R.LeB. \& Jennings, C.E., 2006. On the formation of the tunnel valleys of the southern Laurentide ice sheet. Quaternary Science Reviews 25, 1364-1372.

Houmark-Nielsen, M., 2003. Signature and timing of the Kattegat Ice Stream: onset of the Last Glacial Maximum sequence at the southwestern margin of the Scandinavian Ice Sheet. Boreas 32, 227-241.

Houmark-Nielsen, M. \& Kjær, K.H., 2003. Southwest Scandinavia, 40-15 kyr BP: palaeogeography and environmental change. Journal of Quaternary Science 18, 769-786.

Houmark-Nielsen, M. \& Piotrowski, J.A., 2000. International Field Symposium on Quaternary Geology in Denmark (INQUA Commission on Glaciation; The Peribaltic Group), University of Aarhus, Excursion guide, $32 \mathrm{pp}$.

Jennings, C.E., 2006. Terrestrial ice streams - a view from the lobe. Geomorphology 75, 100-124.

Jørgensen, F. \& Piotrowski, J.A., 2003. Signature of the Baltic Ice Stream on Funen Island, Denmark during the Weichselian glaciation. Boreas 32, 242-255.

Kalm, V., 2012. Ice-flow pattern and extent of the last Scandinavian Ice Sheet southeast of the Baltic Sea. Quaternary Science Reviews 44, 51-59.

Karczewski, A., 1968. Wpływ recesji lobu Odry na powstanie i rozwój sieci dolinnej Pojezierza Myśliborskiego i Niziny Szczecińskiej [Influence of the Odra Lobe recession upon the origin and development of the valleys net of Myślibórz Lakeland and Szczecin Lowland]. Prace Komisji Geograficzno-Geologicznej PTPN 8, 1-106.

Karczewski, A., 2001. Parseta lobe - Pomeranian Phase (Central Pomerania). [In:] J.A Piotrowski \& W. Wysota (Eds): Drumlins: The unsolved problem - Field Excursion Guide Book, $6^{\text {th }}$ International Drumlin Symposium, Nicholas Copernicus University, INQUA Commission on Glaciation, 88-90.

Keilhack, K., 1898. Die Stillstandslagen des letzten Inlandeises und die hydrgraphische Entwicklung des pommerschen Küstengebietes. Jarbuch der Preussischen Geologischen Landesanstalt und Bergakakademie 19, 90-152.

Lasberg, K. \& Kalm, V., 2013. Chronology of the Late Weichselian glaciation in the western part of the East European Plain. Boreas 42, 995-1007.

Marks, L., 2002. Last Glacial Maximum in Poland. Quaternary Science Reviews 21, 103-110.

Marks, L., 2005. Pleistocene glacial limits in the territory of Poland. Przeglad Geologiczny 53, 988-993.

Mojski, J.E., 2005. Ziemie polskie w czwartorzędzie. Zarys morfogenezy [The area of Poland in Quaternary. Outline of morphogenesis]. Polish Geological Institute, Warszawa, 404 pp.

Piotrowski, J.A., 1994. Tunnel-valley formation in northwest Germany - geology, mechanisms of formation and subglacial bed condition for the Bornhöved tunnel valley. Sedimentary Geology 89, 107-141.

Piotrowski, J.A., 1997a. Subglacial groundwater flow during the last glaciation in northwestern Germany. Sedimentary Geology 111, 217-224.

Piotrowski, J.A., 1997b. Subglacial hydrology in north-western Germany during the last glaciation: groundwater flow, tunnel valleys and hydrogeological cycles. Quaternary Science Reviews 16, 169-185.

Piotrowski, J.A., Bartels, F., Salski, A. \& Schmidt G., 1996. Geostatistical Regionalization of Glacial Aquitard Thickness In Northwestern Germany, Based on Fuzzy Kriging. Mathematical Geology, 28: 437-452.

Piotrowski, J.A., Hermanowski, P. \& Piechota, A.M., 2009. Meltwater discharge through the subglacial bed and its land-forming consequences from numerical experiments in the Polish lowland during the last glaciation. Earth Surface Processes and Landforms 34, 481-492.

Punkari, M., 1997. Glacial and glaciofluvial deposits in the interlobate areas of the Scandinavian Ice Sheet. Quaternary Science Reviews 16, 741-753.

Przybylski, B., 2008. Geomorphic traces of a Weichselian ice stream in the Wielkopolska Lowland, western Poland. Boreas 37, 286-296.

Rinterknecht, V., Braucher, R., Böse, M., Bourlès, D. \& Mercier, J.-L., 2012. Late Quaternary ice sheet extents in northeastern Germany inferred from surface exposure dating. Quaternary Science Reviews 44, 89-95.

Smith, A.M. \& Murray, T., 2009. Bedform topography and basal conditions beneath a fast-flowing West Antarctic ice stream. Quaternary Science Reviews 28, 584-596.

Stokes, C.R., Clark, C.D., Lian, O.B. \& Tulaczyk, S., 2007. Ice stream sticky spots: A review of their identification and influence beneath contemporary and palaeo-ice streams. Earth Science Reviews 81, 217-249.

Szewczyk, J., Nowicki, Z. \& Gientka, D., 2007. Występowanie głębokiej zmarzliny w okresie zlodowacenia Wisły na obszarze Niżu Polskiego - implikacje paleohydrogeologiczne oraz geotermiczne [Evaluation of the deep Vistulian permafrost on Polish Lowlands geothermal and paleohydrogeological implications). Wspótczesne Problemy Hydrogeologii 13, 203-211.

Tulaczyk, S., Kamb, B. \& Engelhardt, H.F., 2000. Basal mechanics of ice stream B, West Antarctica. I. Till mechanics. Journal of Geophysical Research 105, 463-482.

Walder, J.S., 1982. Stability of sheet flow of water beneath temperate glaciers and implications for glacier surging. Journal of Glaciology 28, 273-293.

Woldstedt, P., 1931. Über Randlagen der letzten Vereisung in Ostdeutchland und Polen und über die Herausbildung des Netze-Warthe Urstromtales. Jahrbuch der Preussischen Geologischen Landesanstalt 52, 59-67.

Wysota, W., 2007. Successive subglacial depositional processes as interpreted from basal tills in the Lower Vistula valley (N Poland). Sedimentary Geology 193, 21-31. 